\title{
Profesor Lucjan Kurylcio — wspomnienie (1932-2013)
}

W dniu 16 marca br. odszedł Profesor Lucjan Kurylcio. Większą część swojego życia zawodowego poświęcił chirurgii onkologicznej. Z głębokim przekonaniem nazywam go twórcą uniwersyteckiej chirurgii onkologicznej na Lubelszczyźnie. Był założycielem i pierwszym szefem Kliniki Chirurgii Onkologicznej. Kierował nią przez 17 lat, a potem - jako emerytowany profesor chirurgii — z troską czuwał nad jej dalszym rozwojem w kierunku, który sobie wymarzył, a który był realizowany przez jego wychowanków i współpracowników.

Urodził się w Kołkowie koło Pińczowa 29 września 1932 roku. Tam uczęszczał do szkoły powszechnej, a następnie do Liceum im. Hugona Kołłątaja. W czasie okupacji, jako 12-letni harcerz Szarych Szeregów, brał udział w akcjach sabotażowych, a później działał w zakonspirowanym Związku Harcerstwa Polskiego, za co więziono go na przełomie lat 1950/51.

Zanim rozpoczął w 1955 roku studia na Wydziale Lekarskim AM w Lublinie, miał już za sobą kielecką szkołę felczerską oraz kilka lat pracy w pogotowiu ratunkowym w Pińczowie i Aleksandrowie Łódzkim. Już na studiach rozpoczął pracę asystenta w Zakładzie Anatomii Prawidłowej pod kierunkiem prof. Mieczysława Stelmasiaka. Miał ogromne serce do zajęć dydaktycznych ze studentami medycyny, może dlatego, że pochodził z rodziny nauczycielskiej. W 1961 roku uzyskał dyplom lekarza. Obok pracy w Zakładzie Anatomii rozpoczął specjalizację z chirurgii w I Klinice Chirurgicznej przy ul. Jaczewskiego, którą wówczas kierował przedstawiciel Lwowskiej Szkoły Chirurgicznej - prof. Tadeusz Jacyna-Onyszkiewicz, a później jego uczeń i współpracownik - prof. Mieczysław Jesipowicz. W 1969 r. dr Lucjan Kurylcio uzyskał specjalizację II stopnia z chirurgii ogólnej. W tym samym roku obronił rozprawę doktorską pt. Pnie błędne i ich gałęzie w aspekcie wagotomii wybiórczej. W latach 1960-85 publikował prace o układzie nerwowym i naczyniowym, anatomii nerwów błędnych, chorobie wrzodowej żołądka i dwunastnicy, chorobach dróg żółciowych i nowotworach jelita grubego. W 1981 roku, przedstawiając rozprawę pt. Doświadczalna i kliniczna ocena odnerwienia zwieracza bańki wątrobowo-trzustkowej w leczeniu zaburzeń odpływu żółci, uzyskał stopień doktora habilitowanego.

W 1985 roku objął stanowisko ordynatora, a następnie kierownika Kliniki Chirurgii Onkologicznej AM w Specjalistycznym Szpitalu Onkologicznym, późniejszym Centrum Onkologii Ziemi Lubelskiej. W tym czasie był prodziekanem Wydziału Lekarskiego, członkiem Senatu oraz Komisji ds. Restrukturyzacji AM. W 1990 roku Prezydent Rzeczypospolitej Polskiej nadał mu tytuł profesora. Wydarzeniem było złożenie przez niego w 1991 roku - już jako profesora - centralnego egzaminu specjalizacyjnego w dziedzinie chirurgii onkologicznej. W dalszym ciągu pracował naukowo, publikując prace nt. leczenia popromiennych przetok odbytniczo-pęcherzowych, rekonstrukcji dróg łzowych, spływu chłonnego do węzła wartowniczego w raku piersi i czerniaku skóry. W 1987 roku zorganizował w Lublinie Zjazd Sekcji Chirurgii Onkologicznej Towarzystwa Chirurgów Polskich, którego tematem wiodącym były przerzuty do węzłów chłonnych. W latach 90. wdrożył do praktyki klinicznej leczenie oszczędzające oraz rekonstrukcje u chorych na raka piersi. Był promotorem nadania w 1993 roku godności doktora honoris causa AM w Lublinie prof. Zbigniewowi Paplińskiemu.

W 2001 roku kierowana przez niego Klinika Chirurgii Onkologicznej z Oddziałem Chemioterapii przeniosła się do PSK1 przy ul. Staszica.

Profesor był kierownikiem 15 specjalizacji, promotorem 7 doktoratów i opiekunem 1 rozprawy habilitacyjnej. Jego wychowankowie i współpracownicy są dzisiaj ordynatorami oddziałów chirurgii onkologicznej na Lubelszczyźnie. Polskie Towarzystwo Chirurgii Onkologicznej w obliczu jego zasług nadało mu godność Członka Honorowego, które przyjął z rąk swojego przyjaciela prof. Andrzeja Kułakowskiego w roku 2009.

Opatrzność wielokrotnie wystawiała na próbę jego odporność i wiarę. Jako chłopiec był świadkiem rozstrzelania 
swojego ojca w 1944 roku. W roku 1996 został wdowcem, zaś w wieku 76 lat pochował przedwcześnie zmarłą córkę, a jeszcze wcześniej — tragicznie zmarłego zięcia. Był dobrym ojcem i wzorem dla syna, który kontynuuje tradycje chirurgiczne, oraz dobrym dziadkiem trojga wnuków.

Przez cały okres pracy na stanowisku ordynatora w Centrum Onkologii, a następnie kierownika Kliniki, poza działalnością dydaktyczną prowadzono pod jego kierunkiem badania nad leczeniem czerniaka skóry przy pomocy niespecyficznej szczepionki; badania odpowiedzi humoralnej i komórkowej w czerniaku i raku pęcherza moczowego stały się przyczynkiem do stosowania immunoterapii. Opracowano własną metodę leczenia popromiennych przetok odbytniczo-pochwowych i/lub odbytniczo-pęcherzowych. Dokonano pierwszych rekonstrukcji dróg łzowych w raku kąta przyśrodkowego powiek i oczodołu. Badania spływu chłonnego do węzła wartowniczego przyczyniły się do wprowadzenia leczenia oszczędzającego chorych, głównie na raka gruczołu piersiowego i czerniaka oraz rekonstrukcji piersi przy pomocy płatów skórno-mięśniowych lub endoprotez. Wdrożenie badań wartowniczych węzłów chłonnych, a także zachowanie węzłów położonych zewnętrznie od pęczka piersiowo-grzbietowego pozwoliło zapobiec obrzękom kończyny górnej po mastektomii oraz kończyny dolnej, głównie po leczeniu czerniaka. Wykazano korzyści chemioterapii indukcyjnej w leczeniu raka gruczołu piersiowego, jak również i to, że obecność ekspresji onkogenu C-myc w komórce raka świadczyć może o dużej jego złośliwości i krótkim czasie wolnym od choroby, a markery peroksydacji lipidów oraz wydolności antyoksydacyjnej ustroju mogą być przydatnym wskaźnikiem w diagnozowaniu raka piersi. Dokonano także, wówczas pierwszej w Lublinie, analizy częstotliwości występowania receptorów estrogenowych i progesteronowych u chorych operowanych z powodu raka piersi, a także analizy przebiegu klinicznego rzadkich odmian histopatologicznych tego raka, zwracając uwagę, że chore te winne być częściej poddawane zabiegom oszczędzającym. Wszystkie te zagadnienia zostały opublikowane w czasopismach polskich i zagranicznych. Profesor Kurylcio był autorem 165 prac oryginalnych i komunikatów zjazdowych.

W 2006 roku, gdy od czterech lat był już na emeryturze, Walne Zgromadzenie Polskiego Towarzystwo Chirurgii Onkologicznej wybrało go jednogłośnie na Przewodniczącego Sądu Koleżeńskiego.

Profesor Lucjan Kurylcio był kochany i szanowany przez wszystkich pracowników Kliniki, która była jego drugim domem.

Prof. dr hab. n. med. Wojciech Polkowski

Kierownik Kliniki Chirurgii Onkologicznej

Uniwersytet Medyczny w Lublinie

e-mail:wojciech.polkowski@umlub.pl 